\title{
Ionic Wind Drying for Leaves of Andrographis Paniculata Bush Plant
}

\author{
Sumariyah $^{1^{*}} \quad$ Ainie Khuriati $^{1} \quad$ SH Pratiwi $^{1} \quad$ Enny Fachriyah ${ }^{2}$ \\ 1.Physics Department, Mathematics and Sciences Faculty, Diponegoro University, Indonesia \\ 2.Chemistry Department, Mathematics and Sciences Faculty, Diponegoro University, Indonesia
}

\begin{abstract}
Ionic wind drying or High Electric Field Drying is a convective drying technique. It is a non-thermal plasma technology that can effectively remove product moisture whilst retaining heat-sensitive. The purpose of this study was to determine the physical characterization of the dried Andrographis paniculate leaves. The ionic wind is generated using high voltage DC $4 \mathrm{kV}$ is applied on the pin-three rings concentric electrode by the distance between the $4 \mathrm{~mm}$ electrodes. Drying time is 5 to 35 minutes at 5 minute intervals. The results showed that the bitter leaf experienced a reduction in mass during drying and obtained values of the drying rate of $11 \times 10^{-3} \mathrm{db} / \mathrm{min}$, shrinkage of $10.5 \%$ and energy efficiency of $2086 \mathrm{~kJ} /$ gram at 30 minutes.
\end{abstract}

Keywords: Ion wind drying, Drying rate. Shrinkage, Andrographis paniculate leaves

DOI: $10.7176 /$ APTA/83-04

Publication date: February $29^{\text {th }} 2020$

\section{Introduction}

Andrographis paniculate (the bitter leaf) is one of the many medicinal plants found in Asia (Kanniappan, Mathuram, \& Nataraja, 1991). This plant contains a compound of diterpene, lactone, and flavonoids functioning as antiviral and antibacterial (Chao, \& Lin, 2010). Leaves of this plant can be used for the treatment of diarrhea, dysentery, diabetes, toothache and high blood pressure (Pratama,. \& Ramadhan, 2013). In general, the leaves of Andrographis paniculate are processed into drugs on a micro scale or industry which must pass the production stage one of which is the drying process (Moradi \& Zomorodian, 2009).. Drying is one of the most important processes in various industries, especially the pharmaceutical industry (Gumusay, Borazan, Ercal, , \& Demirkol, 2015).. In general, industrial scale drying uses machines (Bruijn, \& Bórquez, 2014). ovens (Moradi, \& Zomorodian ,2009) and hot steam (Chapchaimoh, Poomsae-ad, Wiset, \& Morris, 2016). However, the drying method requires high electrical power and is expensive (Bajgai, \& Hashinaga, 2001). to overcome this there is a drying method using plasma technology, namely ionic wind drying or high electric field drying (Hanafizadeh, Gharahasanlo, Ahmadi, Zeraati, \& Behabadi, 2016). The principle of ionic wind drying is ionization between charges between the two electrodes connected at high voltage (Kulacki, 1982, producing an electric field and ionic wind ( Martynenko , \& Kudra, 2016). The electric field and ionic reduced water content in the material and a drying process occurs (Weber, Borup, Darling, Das, Dursch, \& Gu, 2015). The advantages of ionic wind drying are low power consumption, saving and environmentally friendly (Kudra, \& Martynenko, 2015).. Ion wind drying has also been implemented in various samples (Sumariyah, Khuriati, Pratiwi, \& Fachriyah, 2018 \& 2019). However, in this study using bitter leaf samples with a variation of drying time of 5-35 minutes with 5 minute intervals aimed to determine the characteristics of the bitter leaf during drying and drying rate values (Doymaz, 2012), shrinkage (Mohsenin, 1986), and specific energy consumption (Cao, Nishiyama, \& Koide, 2004).

\section{Method}

\subsection{Sample and experimental preparation}

The sample used was the leaf of Andrographis paniculate obtained from Kediri city, East Java, Indonesia with $39.8 \%$ humidity and a mass of 300 grams that was put into a Petri dish (Normax Glass).

Ion wind drying uses a concentrated of pin-three rings reactor with an amount of $10 \mathrm{x} 10$ pairs of electrodes. The pins electrode $0.026 \mathrm{~mm}$ in diameter. Concentric three-ring electrodes consist of 3 concentric ring electrodes having thicknesses of $2 \mathrm{~mm}$ and $8 \mathrm{~mm}, 16 \mathrm{~mm}$ and $24 \mathrm{~mm}$ respectively. The distance between the two electrodes is $4 \mathrm{~mm}$. The ion wind drying time is 5 to 35 minutes with a time interval of 5 minutes with a $4 \mathrm{kV}$ DC (Direct Current) voltage obtained a current of $20 \mathrm{~mA}$. The DC voltage source is connected to a high voltage divider (SEW high voltage probe P20 P28), so the input voltage can be read by a digital voltmeter (CD772 Sanwa Made in Tokyo, Japan) with unit of $\mathrm{kV}$.

The input voltage will flow in the $10 \times 10$ pairs of pin- three ring reactor systems resulting in the process of ionization and recombination between charges, electrons, and ions in the atmosphere. The ionization process of air in the space of electrode will produce an output current from pin electrode to three ring electrode that is measured using an analog multimeter (Sanwa YX360TRF, Sanwa Electric Instrument CO., LTD, Tokyo, Japan) with $\mathrm{mA}$ and an ionic wind which is move though hole beetween ring resulting in the reduction the concentration of water in the Sambiloto leaves (Pour., \& Esmaeilzadeh, 2011). and mass changes occur during the drying process. 
For the ion wind drying scheme is shown in Figure 1.

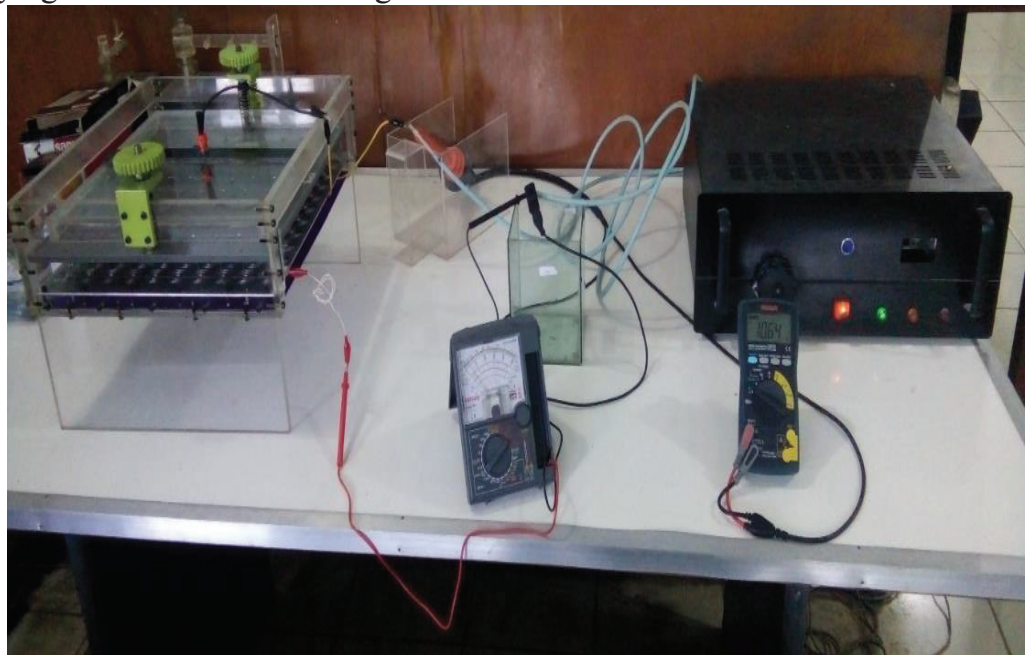

Figure 1. Scheme of research equipment series

\subsection{Applications of HMS}

The mass of Andrographis paniculate leaves was measured before and after drying for 30 minutes. The drying rate (DR) is calculated using Eq. (1) and expressed as db / minute.

$$
D R=\frac{\Delta m}{\Delta t}
$$

Where, $\Delta m$ is the difference in mass after and before drying $(d b), \Delta t$ is the difference in time after and before drying (minutes).

\subsection{Shrinkage}

Depreciation on potato slices is affected by the condition of the initial moisture content in the sample (100\%) at each mass difference in the sample slices dried. Depreciation can be calculated using equation (2) and expressed as $(\%)$.

$$
S R=\frac{\Delta m}{m_{0}} \times 100 \%
$$

Where, $\Delta m$ is the difference in mass after and before drying $(d b), m_{0}$ is the mass before drying $(d b)$

\subsection{Moisture Content}

The water content in the potato slices is different after drying EHD, with an initial humidity of $46.6 \%$. The moisture content of the sample slices can be calculated using equation (3) and expressed as $(\% \mathrm{db})$.

$$
M C=\frac{\Delta m}{m_{0}} \times 46,6 \%
$$

Where, $\Delta m$ is the mass difference after and before drying $(d b), m_{0}$ is the mass before drying $(d b)$.

\subsection{The Specific Energy Consumption}

Specific Energy Consumption is determined from the electric power supplied $(\mathrm{kW})$ and the drying rate $(\mathrm{kg} / \mathrm{s})$ on potato slices which can be calculated in equation (4) as (kJ/gr).

$$
\eta=\frac{V I}{\Delta m} \times \Delta t
$$

Where, $\Delta m$ is the mass difference after and before drying $(d b), \Delta t$ is the time difference after and before drying (minutes), $V$ is the input voltage $(k V)$, and I is the current output $(m A)[$.

\section{Result and Discussion}

3.1 Voltage Current Characterization

Current and voltage characterization curves on bitter leaf drying are shown in Figure 2. 


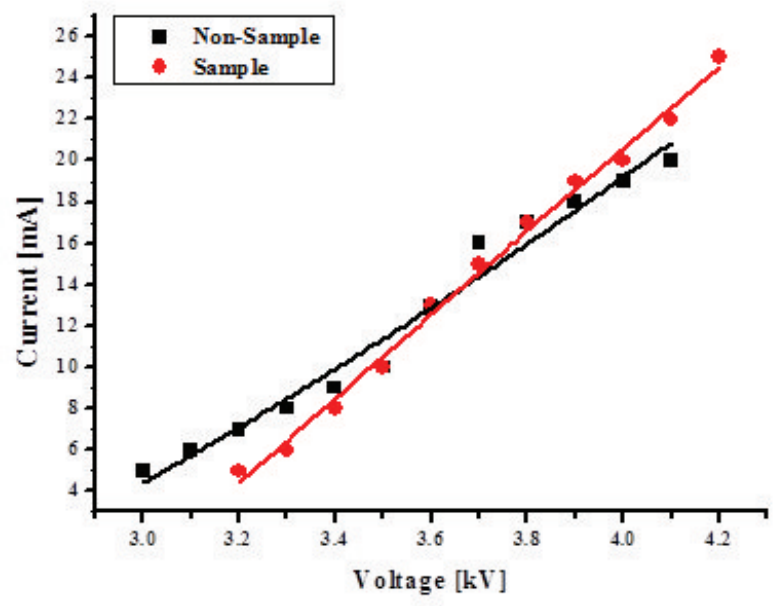

Figure 2. Current and voltage characterization curvel

Figure 2 shows that the current increases with increasing input voltage when there are with sample and with out samples were drained. this is due to the presence of ionized strong electric fields (Sumariyah, Kusminarto, Nuswantoro, \& Rahmanto, 2016). The ionization process at $4 \mathrm{kV}$ produces an increase in the electric field and heat transfer (Martynenko, \& Kudra, (2016). resulting in the evaporation of the mass of water and an increase in the current formed.

\subsection{Voltage Current Characterization}

Drying the bitter leaf with time variation of 5-35 minutes with a time interval of 5 minutes at a voltage of $4 \mathrm{kV}$ obtained the level of drying in Figure 3.

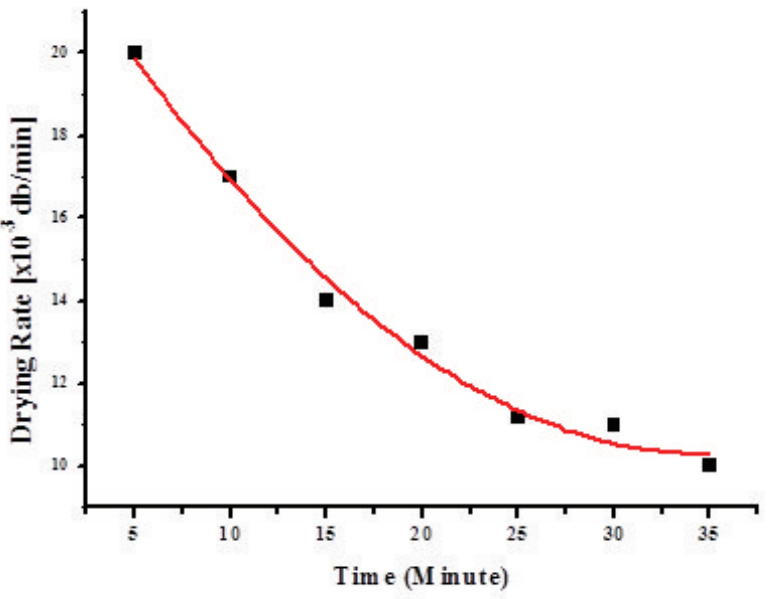

Figure 3. Curve rate of bitter leaf drying

Figure 3 shows that the drying rate decreases with increasing time allotted. At the 35 th minute the smallest drying rate is $10 \times 10^{-3} \mathrm{db} / \mathrm{min}$, this is due to the longer ionization process which will reduce the drying rate in the sample and increase the reduction in mass in the bitter leaf ( Pertiwi \& Susanto, 2014).

\subsection{Shrinkage}

The process of drying the "bitter leaf" of Andrographis paniculate, shrinkage will occur as shown in Figure 4. 


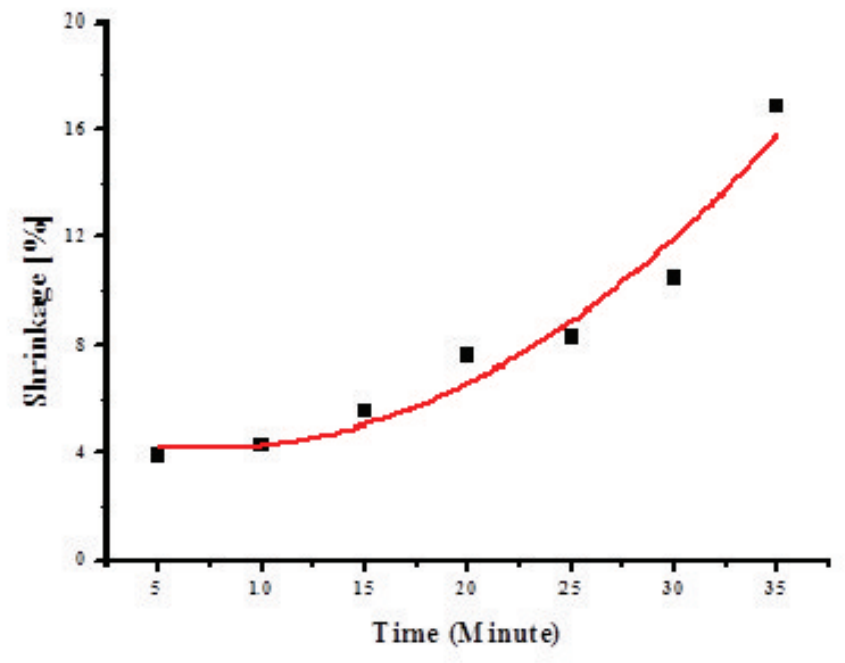

Figure 4. Curvature curve of bitter leaf

Figure 4 shows that, shrinkage increases with increasing drying time. The same shrinkage also was founded evolution during drying of tropical fruits (Talla, Puiggali, Jomaa ,\& Jannot, 2004). This is due to the osmosis process that lasts a long time and heat transfer which results in damage to cell walls in the sample (Hashinaga, Bajgai, Isoble, \& Barthakur, 1999). In minutes $35^{\text {th }}$ the highest mass depreciation was $16.9 \%$

The graph in Figure 4 shows that weight shrinkage is a function of second order polynomials as a function of ion wind exposure time.

\subsection{The Specific Energy Consumption}

The specific energy consumption is defined as amount of energy needed to evaporate unit mass of water in $\mathrm{kJ} \cdot \mathrm{kg}^{-1}$. To calculate the value the specific energy consumption of the bitter leaf of each drying treatment for multiple needles-to-plate electrode under AC electric field. In Figure 5 shows the value of Specific

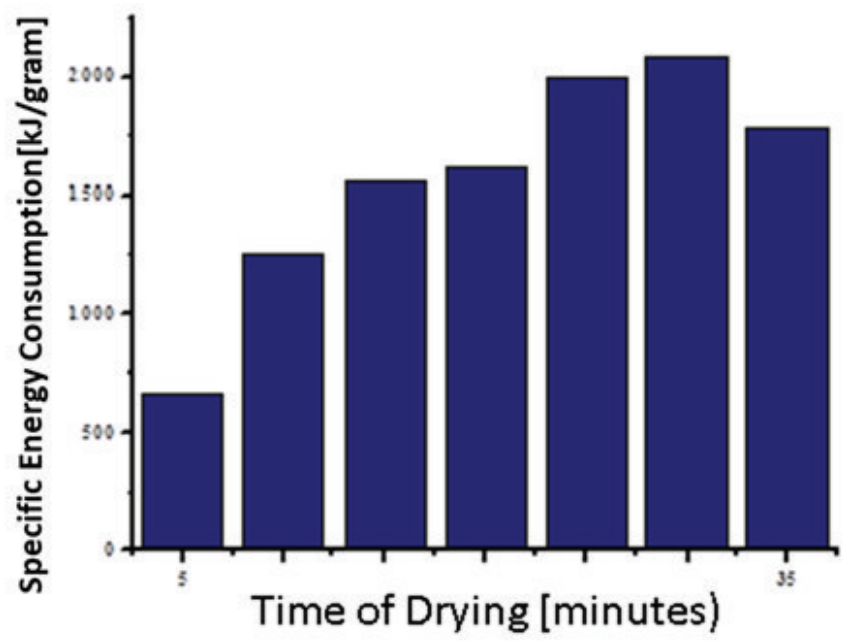

Figure 5. Energy efficiency Curve

In Figure 5 shows, the Energy Efficiency value increases with the increasing time given (Cao, Nishiyama, $\&$ Koidel, 2004), but in the 35 th minute, there is a decrease of $1783 \mathrm{~kJ} / \mathrm{gram}$ caused by the diffusion process. The diffusion process causes the water content towards the surface of the sample again because of the difference in concentration from high to low and a decrease in the electron produced (Dinani, Havet, Hamdami, \& Shahedi, 2014).

\section{Conclusion}

Ion wind drying can be used for drying bitter leaves. The resulting current will increase with the increasing voltage 
applied to the dryer system both without samples and with samples. Ion wind drying at $4 \mathrm{kV}$ produces a current of $20 \mathrm{~mA}$. The drying rate decreases as increasing drying time. Shrinkage and energy efficiency increases with increasing drying time. The most optimal drying time is the $30^{\text {th }}$ minute, it is found that the degree of drying is 11 x $10^{-3} \mathrm{db} / \mathrm{min}$, shrinkage of $10.5 \%$ and energy specific consumption of $2086 \mathrm{~kJ} / \mathrm{gram}$.

\section{Acknowledgements}

The authors would like to thank the University of Diponegoro who has approved this research so that it can be funded by the Directorate of Research and Community Service of the Ministry of Research, Technology and Higher Education according to the Letter of Assignment of Superior Research of Higher Education (PUPT) Number: 101-121/UN7.P4.3/PP/2019

\section{References}

Bajgai,T.R., Hashinaga,F., (2001), High electric field drying of Japanese radish, Dry. Technol., 19, pp. 2291-2302 Bruijn , J. Bórquez,R. (2014), Quality retention in strawberries dried by emerging dehydration methods, Good Research International, 63 (Part A), pp. 42-48

Cao, W., Nishiyama, Y., Koidel, S., (2004). Electrohydrodynamic drying characteristics of wheat using high voltage electrostatic field. J. Food Eng. 62, 209-213

Chapchaimoh, K., Poomsae-ad, N., Wiset, L., Morris, J., (2016), Thermal Characteristics of heat pump dryer for ginger drying, Applied Thermal Engineering 95 491-498

Chao, W.W. and LIN, B.F. (2010), Isolation and identification of bioactive compounds in Andrographis paniculate (Chuanxinlian), Chinese Medicine. 5:1-15.

Dinani, S.T., Havet, M., Hamdami, N., Shahedi, M., (2014). Drying of mushroom slices using hot air combined with an electrohydrodynamic drying system. Drying Technol. 32 (5), 597-605

Doymaz,I., (2012), Evaluation of some thin-layer drying models of persimmon slices (Diospyros kaki L.), Energy Convers Manage, 56, pp. 199-205

Gumusay, O.A., Borazan, A.A., Ercal, N., and Demirkol, O., (2015), Drying effects on the antioxidant properties of tomatoes and ginger, Food Chemistry 173, 156-162

Hanafizadeh, P., Gharahasanlo, M., Ahmadi, S., Zeraati, S., Akhavan-Behabadi, M.A., (2016), Numerical investigation of ANGIN ION effects on heat transfer enhancement and flow pattern of R134a two-phase flow, Journal of Electrostatics 82, 63-71

Hashinaga, F., Bajgai, T.R., Isoble, S., Barthakur, N.N., (1999). Electrohydrodynamic (ANGIN ION) drying of apple slice. Drying Technol. 17 (3), 479-483

Kudra, T., Martynenko,A.,(2015), Energy aspects in electrohydrodynamic drying, Drying Technology, 33 (13), pp. $1534-1540$

Kanniappan, M., Mathuram, L.N., Natarajan, R., (1991). A study on the antypiretic effect of Chiretta (Andrographis paniculata). Indian Veterinary Journal 68, 314-316.

Kulacki,F.A., (1982), Electrohydrodynamic enhancement of convective heat and mass transfer,A.S. Mujumdar, R.A. Mashelkar (Eds.), Advances in transport processes, Wiley Eastern Ltd., New York, pp. 105-147

Martynenko A., Kudra, T., (2016), Electrically-induced transport phenomena in Ionic wind drying e A review, Trends in Food Science \& Technology 54, 63-73

Mohsenin,N.N (1986), Physical Properties of Plant and Animal Materials, Gordon and Breach Science Publishers, New York, USA (1986)

Moradi, M., Zomorodian, A., (2009), Thin Layer Solar Drying of Cuminum Cyminum Grainsby Means of Solar Cabinet Dryer. American-Eurasian J. Agric. \& Environ. Sci. ; 5(3): 409-413.

Pertiwi, M.F.D., and Wahono Hadi Susanto,W.H., (2014), The Influenceof Proportion (Fruit : Sucrose) and Osmosis Time on The Qualityof Strawberry Juice (Fragaria vesca L), Kualitas Sari Buah Stroberi - Pertiwi, dkk Jurnal Pangan dan Agroindustri Vol.2 No.2 p.82-90

Pour, M. S., \& Esmaeilzadeh, E., (2011), Experimental investigation of convective heattransfer enhancement from 3D-shape heat sources by ionic wind actuator in duct flow. Experimental Thermal and Fluid Science, 35, $1383 \mathrm{e} 139$

Pratama,, B.A. \& Ramadhan, D.F. (2013). Khasiat Tanaman Obat Herbal. Jakarta : Pustaka Media.

Sumariyah, A Khuriati, S H Pratiwi, and E Fachriyah, (2019), Ion wind from yield corona discharge and its application to drying of Turmeric slices (Curcuma domestica Val), IOP Conf. Series: Journal of Physics: Conf. Series 1170, 012026

Sumariyah, A Khuriati, E Fachriyah, and S H Pratiwi, (2019), Determination of ion wind velocity using the method of characteristics (MOC) and its application for drying of black turmeric (Curcuma aeruginosa Roxb) slices, IOP Conf. Series: Journal of Physics: Conf. Series 1217, 012025

Sumariyah, A. Khuriati, and E. Fachriyah, (2018), On Wind Generation And Its Application To Drying Of Wild 
Ginger Slices (Curcuma Xanthorhiza), IOP Conf. Series: Journal of Physics: Conf. Series 1025, 012016

Sumariyah, Kusminarto, Nuswantoro,P., and Rahmantol,A.,( 2016), Study of ion wind flow generator's efficiencies utilizing pin to single ring and multi-concentric rings electrodes, Journal of Physics: Conference Series 776012100

Talla, A., Puiggali, J.R., Jomaa, W., Jannot, Y., (2004). Shrinkage and density evolution during drying of tropical fruits: application to banana. J. Food Eng. 64, 103-109

Weber,A.Z., Borup,R.L., Darling,R.M., Das,P.K., Dursch,T.J., Gu,W., et al. (2015), A critical review of modeling transport phenomena in polymer-electrolyte fuel cells, Journal of the Electrochemical Society, 161 (12), pp. F1254-F1299 